\title{
The Process of Neolithisation in South-Eastern Poland - Selected Problems
}

\author{
Sławomir Kadrow ${ }^{a}$
}

\begin{abstract}
The article is devoted to a critical discussion of the current concepts of the Neolithisation of Polish lands - from the migration models of colonisation to those that do not exclude the participation of the indigenous Mesolithic population in this process. None of the cited concepts explores the socio-cultural, internally conditioned, mechanisms of this epochal change. In the context of these mechanisms, one should look for the necessary and sufficient conditions for the change to occur, in the form of conscious (or more often unconscious) reinterpretation of symbols, norms and socio-cultural structures. This text outlines a fresh area to be explored in future studies of Neolithisation.
\end{abstract}

KEY-WORDS: Early Neolithic, Mesolithic, Polish lands, Neolithisation, Danubian cultures.

\section{INTRODUCTION}

The aim of the article is to outline a fresh area to be explored in future studies of Neolithisation. As a method of achieving this goal, the author reviews the most important, in his opinion, concepts of this process in Polish archaeology in order to reconstruct its sources and mechanisms. This review is to highlight the fields of achievement and deficiencies in these studies. As a result, this allows an indication of new, theoretical research perspectives. The aspect of genetic and isotope research was deliberately omitted when studying the process of Neolithisation due to the scarcity of relevant analyses from the area of Poland.

The review of views on the nature of the Neolithisation of Polish territories, presented in the archaeological literature from the I920s to the present day, shows their significant evolution. The literature was initially dominated by migration models of colonisation of these areas by groups of the Danubian population. Later, the participation of the domestic Mesolithic population in this process was increasingly accepted.

a Institute of Archaeology, Rzeszów University, io Moniuszki st., 35-ors Rzeszów, Poland, e-mail: slawekkadrow@gmail.com ORCID: 0000-0002-7169-IO27 
So far, the concept of existence of a Pre-Pottery Neolithic period in the Polish lands has not been confirmed.

\section{HISTORICAL AND CULTURAL CONCEPTS}

Włodzimierz Antoniewicz wrote (1928: 39) that around 4000 BC: [...] the persistence of drought in the fertile Danubian steppes caused quite large groups of settlers to set off along the great riverbeds west to the Rhine countries; as well as north through Moravia to Silesia and to Lesser Poland. It was an agricultural people who also knew raising of bovine animals and swine [...] As a result of population growth and rising droughts, followed the migration of this people to further forest-free and fertile areas [...]. The migration of human groups from the south (the Carpathian Basin) to the north (Lesser Poland) did not take the shortest route (through the Western Carpathians), but through Moravia (probably through the Moravian Gate), bypassing the chain of Carpathian Mountains from the west (Antoniewicz 1928: 39-40).

The views of the author of the first synthesis of prehistory of Poland (Antoniewicz 1928) are clearly inspired by Robert Gradmann's theory: Steppenheidentheorie (Gradmann 1906). However, the influence of Gustaf Kossinna on Antoniewicz's views is visible in his thesis that the division of the Early Neolithic cultural groups, made on the basis of stylistic and typological analysis of ceramics, corresponds to ethnic groups (Antoniewicz 1928: 40).

Józef Kostrzewski, a prominent student of G. Kossinna, saw a great economic breakthrough in the prehistory of Polish lands as an effect of the Neolithisation caused by the population from the central Danube migrating to these areas through the Moravian Gate. He calls this population "the folk of Banded Pottery [Bandkeramik]". He concluded that further wanderings of this people to the east (towards Volhynia) and to the south-east (towards Podolia) had taken place along the north and northeastern borders of the Carpathian Mountains chain (Kostrzewski 1949: 29-30).

Konrad Jażdżewski also connected the appearance of the oldest Neolithic in Poland with the migrations of the agricultural populations from the area of Moravia through the Moravian Gate (Kostrzewski et al. 1965: 60-6I). He believed that only the populations of the Bükk culture overcame the "Carpathian barrier" in their journeys from the Slovak-Hungarian borderland to Lesser Poland (Kostrzewski et al. 1965: 69).

According to Jażdżewski: [...] ceramic styles within the Danubian complex are not an expression of differences larger than dialectical varieties within a large language unit or dissimilarity of clothing in different regions of the same population group, or a change in aesthetic preferences of successive generations of what is in principle the same community (Kostrzewski et al. 1965: 60). This statement situates his views in the centre of cultural and historical archaeology, in which the normative concept of archaeological culture 
is of key importance. In another place, he writes that [...] in the first place should be exhausted all available sources indicating to the local development of individual cultures without unnecessary resorting, in the vast majority of cases to the migration theories while interpreting these phenomena (Jażdżewski 198I: 292-294). This quote, in turn, reflects the specificity of the "indigenous school" in Polish archaeology. This, while developing from the Kossinna's Siedlungsarchäologie (and accepting most of its assumptions), rejects migrationism in favour of searching for local roots of the most important cultural phenomena. This position was a reaction to the involvement of Siedlungsarchäologie in the ideological struggle of the Nazis, seeking legitimisation of their political goals in the prehistoric past, in which the picture painted of prehistoric migrations of Germans had played a crucial role (cf. Lech 1998: 34-38, 48-54, 65-78; Kadrow 20II: I32; Kadrow 20I4: I5-I6).

The adherents of cultural and historical archaeology do not give reasons for the postulated expansion of the Danubian cultures population to the areas north of the Carpathian Mountains. On the other hand, as to the reasons for maintaining Trans- or Circum-Carpathian contacts in the Neolithic period and, above all, in the Bronze Age, they see them mainly in the need for obtaining raw materials (such as various kinds of flint, obsidian, amber, copper, etc.). The transmission of ideas and technology was therefore seen as a consequence of supplying themselves in raw materials.

In the I960s, a group of archaeologists worked in Cracow attempting to establish the relative chronology and taxonomy of the Danubian cultures with reference to the "southern" standards (e.g. Kozłowski J. K. I966; Kamieńska 1967; KulczyckaLeciejewiczowa 1968). This group, focusing on the basic problems of the archaeologist's workshop - typology, taxonomy and chronology - consciously placed themselves outside the "neo-autochtonous school". The taxonomic and chronological results of their work (e.g. Kulczycka-Leciejewiczowa 1979: 34-39; Kaczanowski and Kozłowski I998: I04-IO8; Nowak 2009: 89-93), with minor modifications, still function in Polish archaeology to this day. The disambiguation made at that time showed the importance of the Trans-Carpathian (and Trans-Sudetian) relationships, and the researchers mentioned above, without exception, opted for migrations of people from the areas south of the Carpathians and the Sudetes as the driving force of the emergence of the oldest Neolithic in our lands.

Such a basic approach, with some variations, was presented many times by Janusz K. Kozłowski, referring to the idea of adaptation. In his opinion, in the basin of the middle Danube in the middle of the sixth millennium BC a community of farmers and stock herders well adapted to the environment of dense forests had appeared. They produced and used ceramics decorated with incised bands. Due to the lack of evidence for demographic pressure in the starting areas, the migration of representatives of these communities to the north was seen as caused by the search for raw materials, mainly for the production of more "luxury" goods (e.g. Kaczanowski and Kozłowski 1998: I04). 
Initially the groups of people migrating from the south (Pavúk 1980) occupied the loess areas in Lower and Upper Silesia and in Lesser Poland. A little later they arrived in the environs of Rzeszów, to Kuyavia and Chełmno Land. Then they reached western Ukraine and Moldova. The economic model of the population of the Linear Pottery culture in the north corresponds to the pattern of the economy previously developed on the middle Danube (Kaczanowski and Kozłowski 1998: I05; cf. also CzekajZastawny 2008: I2-I5; 2017: 26-27; Kozłowski et al. 20I4: 39; Czekaj-Zastawny and Kabaciński 20I7: IIO).

\section{PRE-POTTERY BEGINNINGS OF THE NEOLITHIC PERIOD IN POLAND}

Jan Kowalczyk (1969) proposed as a thought experiment the hypothetical existence of a Pre-Pottery Neolithic in Polish lands. In the absence of any evidence for this phenomenon at that time, he developed this idea on the premises of general theories of cultural development; he also noted the poor state of the relevant research. This was the justification of the need to make an effort to actively search for traces of this phenomenon, which Kowalczyk (1969: 55-59) was convinced had taken place. Undoubtedly, he took his inspiration in this theory from the proposals of Vladimir Milojčić (1960).

Kowalczyk emphasized that the Neolithic was above all a continuation of the preceding epoch, and not just a revolutionary "leap" (Kowalczyk 1969: 57). He suggested that the beginnings of the Neolithic period in the Polish territories should be examined within three latitudinal zones: the southern, the central and the northern one, taking into account the specificity of north-eastern Poland (Kowalczyk 1969, Fig. 4-5). At the same time, he assumed that in these three zones, a Pre-Pottery Neolithic must have to preceded the pottery-using Neolithic. At the same time, he postulated that the southern zone should be regarded as the northern periphery of the area of the origin of the Linear Pottery culture (Kowalczyk 1969: 58).

In his deliberations, Kowalczyk was deeply rooted in the network of the concepts of cultural and historical archaeology. He considered the tribe to be the basic unit of the organization of human groups (Kowalczyk 1969: 63). This probably prevented him from developing properly his innovative hypothesis about the existence of the PrePottery Neolithic in our lands. The whole concept at first met with severe criticism (Kozłowski J. K. I97I), to be later almost completely forgotten.

\section{THE CONCEPT OF THE PRE-NEOLITHIC}

Stefan K. Kozłowski (1989) noted that in the Late Mesolithic there can be detected a progressive standardization of flint industries. A tendency to increasingly use flint 
raw materials of good quality is also observed. The starting point of these processes were (already in the seventh millennium BC) the Mediterranean areas and there they had their fullest and most expressive course (Kozłowski S. K. 1987: 13-17).

In the six millennium $\mathrm{BC}$, these processes intensified. The production of trapezes, truncated blades, endscrapers and scrapers as well as of the larger and more regular blade blanks increased (Kozłowski S. K. I987: I0; 200I: 267). These inventories resembled industries from the Early Neolithic period and therefore they were called "preNeolithic" (Kozłowski S. K. 1987).

In some Polish territories, the process labelled "pre-Neolithisation" consisted, according to S. K. Kozłowski, of the replacement of the Komornica culture with post-Maglemose cultures, and in the east of Poland - by the Janisławice culture, which had connections with the Black Sea area (Kozłowski S. K. 1989: 154-165; 200I: 267). However, the researcher found that [...] the "progressive" pre-Neolithic character of the Janistawice culture did not develop later in the Neolithic direction because [...] the territory that it occupied was "unfavourable" (Kozłowski S. K. 1989: 20I).

\section{“THE INITIAL PHASE OF THE RECEPTION OF THE MANUFACTURING ECONOMY”}

In Kuyavia, at the site 29 in Dęby in the Radziejów county (Domańska 1990), bones of domesticated animals (mainly small ruminants) were discovered along with Mesolithic flint artefacts belonging to the Janisławice culture. This inventory was dated to the end of the seventh millennium BC. The discovery of this site became the basis for the separation of the initial phase of the process of reception of the manufacturing economy (Domańska 1990: 7; 1991; 1998). In this phase, "eastern" elements (remnants of small ruminants) were registered, which were supposed to testify about the participation of Caucasian-Black Sea cultural patterns in the formation of the initial phase (Domańska 1990: 62). The acceptance of Lucyna Domańska’s conclusions would mean that in this case we are dealing with the oldest trace of the manufacturing economy, which, moreover, is not related to the Danubian cultures circle (cf. Nowak 2009: 82).

These theses raised many objections. Among others, it was pointed to the fact that the archaeozoological identifications are questionable (eg. Nowak 2009: 82). Others suggested that the described assemblages were not of a homogenous nature (Kozłowski S. K. I99I: 26). In reply to these criticisms, Domańska presented the results of the pedological and stratifigraphic analysis of the site that had yielded an interesting collection of artefacts, as well as radiocarbon dating results that allowed her to combine this collection with the Janisławice culture and the period 5300-4800 BC (Domańska 199I: 4O-4I). It seems, however, that at the level of source criticism, this dispute is difficult to resolve (cf. Czerniak 1994: 9). 
This hypothesis is mostly falsified by the late dating of the few remains of goat/ sheep in the Bug-Dnieper culture in the Black Sea basin (opinion of Norbert Benecke quoted by Klaus-Peter Wechler: Wechler 200I: 34-45; Kadrow 2007: 257-259), from where the impulses for the existence of the "initial phase" in the Kuyavia region could come from.

\section{PRE-LINEAR AGRICULTURAL COMMUNITIES IN THE POLISH LOWLANDS}

The view about the emergence of elements of the manufacturing economy before the Danubian colonisation is supported by the entire research stream in studies on the Mesolithic and the beginnings of the Neolithic, in which emphasis is on the fluidity of the boundaries between some types of foraging and hunting and agricultural and stock herding activities (e.g. Clarke 1976; Dennell 1983), in contrast to concepts of a sharp Neolithic Revolution postulated by Vere Gordon Childe (1929).

Lech Czerniak (1994: 7-I6), however, also considers that a positive verification of the hypothesis assuming the emergence of elements of the manufacturing economy in the Polish Lowlands before the Danube colonisation can be expected, provided that a larger number of sites of Dęby 29 type will be discovered and investigated (Czerniak 1994: II). In the light of the several ideas discussed above (e.g. Kowalczyk 1969; Kozłowski S. K. 1989; Domańska 1990; 199I; 1998) this is a promising research perspective. However, it is difficult to implement from the practical side (cf. Kozłowski S. K. 1989).

Czerniak claims that in parallel with the formation process of Neolithic communities in the Middle East there was (the question is, whether fully independently?) a process of functionally similar socio-cultural changes among many local gatherer-hunter groups in Europe (Czerniak 1994: II). This phenomenon has also been described as a form of "pre-Neolithic" (Kozłowski S. K. 1989).

Positive verification of this hypothesis would also require demonstrating that the (pre- or proto-Neolithic) Janisławice culture had its beginnings no later than the end of the seventh millennium BC, and that its population was already in contact with the sheep breeding communities inhabiting the Dniester and the Southern Bug (Boh) basin (Czerniak 1994: I2). Radiocarbon dates, confirming the early dating of the Janisławice culture, and the fact of its adjacency (of the Janisławice-Rudoostrov circle) to the Bug-Dniester culture, make this thesis very probable. It is reinforced by the obvious influence of the Körös culture readable in the oldest ceramics from the Dniester and Southern Bug (Boh) basin. Knowledge of breeding small ruminants could, therefore, have been adopted from the population living in these areas, and not from the Crimea (as references in the Janisławice flint working seem to suggest), but through the Grebienniki culture (Czerniak 1994: I2-I3). Eventually, Czerniak opts for the 
\begin{tabular}{l|l} 
The process of Neolithisation in southeastern Poland-selected problems & $4 I$
\end{tabular}

Körös-Linear Pottery cultures origins of goat/sheep presence at the site 29 in Dęby (Czerniak 1994: 15).

\section{AN INDIRECT ADAPTIVE CONCEPT}

In the Neolithisation of Central Europe, including Poland, the Balkan areas played a decisive role. The discussion about the origin of the oldest Neolithic in Poland and in neighbouring areas has recently been presented by Marek Nowak (2009: 82-87). There are two alternative solutions: colonisation (e.g. Bogucki 200I; 2003; Kaczanowska and Kozłowski 2003) or adaptation (e.g. Mateiciucová 2004; Whittle 2004). There is also no lack of intermediate interpretations (e.g. Gronenborn 1999; Bánffy 2004; Nowak 2004).

According to the "colonisation" concept, the population of the oldest phase of the Linear Pottery culture, which were formed south of the Carpathians and Sudetes, relatively quickly migrated to the loess areas located on the north side of those mountain ranges and settled there in enclave areas. The main argument of this concept is the lack of any local roots of the Neolithic culture elements. The second is the similarity of the oldest pottery of the Linear Pottery culture to vessels of the Starčevo culture (e.g. Pavúk 1980).

The problem is the still poorly documented stage of the formation of the oldest phase of the Linear Pottery culture, i.e. the appearance of its characteristic ornamentation, the localization of this stage and its exact chronology (Nowak 2009: 83).

An important problem is also the issue of the causes of the far-reaching migrations of populations of this culture in its older phase to the north, north-west and northeast. In previous research the demographic (e.g. Cavalli-Sforza and Cavalli-Sforza 1995), ecological-economic (Bánffy 2004), socio-symbolic (Pavlů 2004; Pavúk 2004) or climatic factors (Strien and Gronenborn 2005) have been proposed as the reasons for these migrations. Nowak assumes also the possibility of existence of all the reasons mentioned, and not just one of them (Nowak 2009: 84).

In the migration model, the total lack of participation of local Mesolithic communities in the colonisation is also mysterious (Nowak 2009: 84).

There are several different versions of the "adaptive" concept. The radical versions completely reject the participation of migrants from the south (e.g. Whittle 1996). The indigenous hunter-gatherer populations are thought to have independently adopted the "Neolithisation attributes". In this way they created an original cultural (economic, settlement, social and ideological) quality different from the Balkan one. The weakness of this idea is, according to Nowak, the lack of evidence that would justify it in the sphere of material culture (Nowak 2009: 85). 
The intermediate versions of the adaptive concept are more convincing (e.g. Gronenborn 1999; Bogucki 2000: 197-218; Zvelebil 2004). They accept that there was most probably a migration to the north of a population of Starčevo-Körös origin, who invented linear ornamentation (Nowak 2004; 2009: 86). They settled in enclaves in central Europe in the oldest and older phase of the development of the Linear Pottery culture. These communities were to be the "leaven" of the Neolithic among the Mesolithic population groups, especially in the western zone, on the basis of contact at "fronts" (Bogucki 2000: 218; Zvelebil 200I: 6; Nowak 2009: 86-87). The low intensity of contacts between Mesolithic and Early Neolithic groups is underlined. In Polish territory this is demonstrated by the occasional presence of amber on the sites of the Linear Pottery culture (Czekaj-Zastawny and Kabaciński 20I7: IIO-III).

\section{CONCLUSIONS}

In the concepts quoted above, little space was devoted to the mechanisms of Neolithisation and civilisation changes accompanying it. Sometimes such reflections were limited to pointing out external factors towards the communities involved in the process, in the form of climatic changes (more broadly: environmental) or economic changes that acted as necessary but insufficient conditions for any change (cf. Habermas 1983: 494; Sztompka 2007: 208-212). None of the cited concepts, however, refers to the socio-cultural, internally conditioned mechanisms of this epochal change. In the context of these mechanisms, one should look for the necessary and sufficient conditions for a change to occur, in the form of conscious and more often unconscious reinterpretation of symbols, norms and socio-cultural structures (cf. e.g. Kadrow 20I2: 227-228). This statement outlines a fresh area to be explored in future studies of Neolithisation. An attempt to implement them is a reconstruction of the mechanisms of changes taking place in the Early Neolithic communities in the Rzeszów region (Kadrow 2019).

\section{ACKNOWLEDGMENTS}

This article has benefited from financial support afforded by NCN 2016/2I/B/ $\mathrm{HS}_{3} / 03137$. 
\begin{tabular}{l|l} 
The process of Neolithisation in southeastern Poland-selected problems & 43
\end{tabular}

\section{REFERENCES}

Antoniewicz, W. 1928. Archeologia Polski. Zarys czasów przedhistorycznych i wczesnodziejowych ziem polskich. Warszawa.

Bánffy, E. 2004. The 6th Millennium BC Boundary in Western Transdanubia and its Role in the Central European Neolithic Transition (the Szentgyörgyvölg-Pityerdomb Settlement). Budapest.

Bogucki, P. 2000. How agriculture came to North-Central Europe. In T. D. Price (ed.), Europes First Farmers, 197-216. Cambridge.

Bogucki, P. 200I. Recent research on early farming in Central Europe. Documenta Praehistorica 28: 85-98.

Bogucki, P. 2003. Neolithic dispersal in riverine interior Central Europe. In. A. Ammerman and P. Biagi (eds), The Widening Harvest: the Neolithic Transition in Europe. Looking Back, Looking Forward, 249-272. Boston.

Cavalli-Sforza, L. L. and Cavalli-Sforza, F. 1995. The Graet Human Diasporas. The History of Diversity and Evolution. New York.

Childe, V. G. 1929. The Danube in Prehistory. Oxford.

Clarke, D. L. 1976. Mesolithic Europe: the economic basis. In G. de Giberne Sieveking, I. Longworth and K. Wilson (eds), Problems in Economic and Social Archaeology, 449-482. London.

Czekaj-Zastawny, A. 2008. Osadnictwo spoteczności kultury ceramiki wstęgowej rytej w dorzeczu górnej Wisty. Kraków.

Czekaj-Zastawny, A. 20I7. The first farmers from the south - Linear Pottery culture. In P. Włodarczak (ed.), Polish lands from the first evidence of human presence to the Early Middle Ages, 2I-62. Warszawa. The Past Societies T. 2 - 5500-2000 BC.

Czekaj-Zastawny, A. and Kabaciński, J. 20I7. Hunter-gatherers and the first farmers. In P. Włodarczak (ed.), Polish lands from the first evidence of human presence to the Early Middle Ages, I07-I24. Warszawa. The Past Societies T. 2 - 5500-2000 BC.

Czerniak, L. 1994. Wczesny i środkowy okres neolitu na Kujawach 5400-3650 p.n.e. Poznań.

Dennell, R. 1983. European Economic Prehistory. A new approach. London.

Domańska, L. 1990. Kaukasko-nadczarnomorskie wzorce kulturowe w rozwoju późnomezolitycznych spoteczeństw Niżu strefy pogranicza Europy wschodniej i środkowej. Inowrocław. Studia i materiały do dziejów Kujaw 5.

Domańska, L. 1991. Obozowisko kultury janistawickiej w Dębach, woj. wtoctawskie, stanowisko 29. Poznań-Inowrocław.

Domańska, L. 1998. The initial stage of food-production in the Polish Lowlands - the Dęby 29 site. In M. Zvelebil, L. Domańska and R. Dennell (eds), Harvesting the Sea, Farming the Forest: The Emergence of Neolithic Societies in the Baltic Region, I29-133. Sheffield. Sheffield Archaeological Monographs io.

Gradmann, R. 1906. Beziehungen zwischen Pflanzengeographie und Siedlungsgeschichte. Geographische Zeitschrift 12: 305-325.

Gronenborn, D. 1999. A variation on a basic theme: the transition to farming in Southern Central Europe. Journal of World Prehistory 13: 123-210.

Habermas, J. 1983. Próba rekonstrukcji materializmu historycznego. In J. Habermas, Teoria i praktyka. Wybór pism, 475-532. Warszawa.

Jażdżewski, K. 1981. Pradzieje Europy środkowej. Wrocław.

Kaczanowska, M. and Kozłowski, J. K. 2003. Origins of the Linear Pottery Complex and the Neolithic Transition in Central Europe. In A. J. Ammerman and P. Biagi (eds), The Widening Harvest: the Neolithic Transition in Europe. Looking Back, Looking Forward, 227-248. Boston. 
Kaczanowski, P. and Kozłowski, J. K. 1998. Najdawniejsze dzieje ziem polskich (do VII w.). Kraków. Wielka Historia Polski I.

Kadrow, S. 2007. Kontakty kultur środkowoeuropejskich ze środowiskiem kulturowym na terenach Ukrainy we wczesnym neolicie - wybrane zagadnienia. In L. Bakalarska (ed.), Wspólnota dziedzictwa archeologicznego ziem Ukrainy i Polski. Materiaty z konferencji zorganizowanej przez Ośrodek Ochrony i Dziedzictwa Archeologicznego. Łańcut (26-28.X.2005 r.), 250-269. Warszawa.

Kadrow, S. 20II. The German Influence on Polish Archaeology. In A. Gramsch and U. Sommer (eds), A History of Central European Archaeology. Theory, Methods, and Politics, I25-I4I. Budapest. Archaeolingua: Series minor 30.

Kadrow, S. 20I2. Źródła i mechanizmy zmiany kulturowej. Przypadek wczesnego eneolitu. In B. Gediga, A. Grossman and W. Piotrowski (eds), Rytm przemian kulturowych w pradziejach i średniowieczu, 233-259. Biskupin-Wrocław. Prace Komisji Archeologicznej Polskiej Akademii Nauk - Oddział we Wrocławiu I9.

Kadrow, S. 20I4. Trans-Carpathian Contacts in the Neolithic and the Early Bronze Age. In T. L. Kienlin, P. Valde-Nowak, M. Korczyńska, K. Cappenberg and J. Ociepka (eds), Settlement, Communication and Exchange around the Western Carpathians: International Workshop Held at the Institute of Archaeology, Jagiellonian University, Kraków, October 27-28, 20I2, 13-26. Oxford.

Kadrow, S. 2019. Innovations in ceramic technology in the context of culture change north of Carpathians at the turn of the 6th and 5th millennia BC. In M. Spataro and M. Furholt (eds), Detecting and explaining technological innovation in prehistory, 7I-9I. Leiden.

Kostrzewski, J. 1949. Pradzieje Polski. Poznań.

Kostrzewski, J., Chmielewski, W. and Jażdżewski, K. 1965. Pradzieje Polski. Wrocław.

Kowalczyk, J. 1969. Początki neolitu na ziemiach polskich. Wiadomości Archeologiczne 34(I): 3-69.

Kozłowski, J. K. 1966. Próba klasyfikacji materiałów zaliczanych do kultury lendzielskiej i nadcisańskiej w Polsce południowej. Archeologia Polski II: 7-27.

Kozłowski, J. K. 197I. W sprawie początków neolitu na ziemiach polskich. Wiadomości Archeologiczne 36(I): 44-50.

Kozłowski, J. K., Kaczanowska, M., Czekaj-Zastawny, A., Rauba-Bukowska, A. and Bukowski, K. 2014. Early/Middle Neolithic Western (LBK) vs. Eastern (ALPC) Linear Potter Cultures: Ceramics and Lithic Raw Materials Circulation. Acta Archaeologica Carpathica 49: 37-76.

Kozłowski, S. K. 1987. The pre-Neolithic base of the Early Neolithic stone in Europe. In J. K. Kozłowski and S. K. Kozłowski (eds), Chipped Stone Industries of the Early Farming Cultures in Europe, 9-18. Warszawa. Archaeologia Interregionalis 9.

Kozłowski, S. K. 1989. Mesolithic in Poland. A New Approach. Warszawa.

Kozłowski, S. K. 1991. Neolit preceramiczny na Kujawach? Warszawa.

Kozłowski, S. K. 20or. Eco-cultural/stylistic zonation of the Mesolithic/Epipalaeolithic in Central Europe. In R. Kertész and J. Makkay (eds), From the Mesolithic to the Neolithic. Proceedings of the International Archaeological Conference held in the Damjanich Museum of Szolnok, September 22-27, 1996, 26I-282. Budapest.

Kulczycka-Leciejewiczowa, A. 1968. Ze studiów nad kulturą ceramiki wstęgowej w Polsce. Archeologia Polski 13: 56-I24.

Kulczycka-Leciejewiczowa, A. 1979. Pierwsze społeczeństwa rolnicze na ziemiach polskich. Kultury kręgu naddunajskiego. In W. Hensel and T. Wiślański (eds), Prahistoria ziem polskich, t II: Neolit, I9-I64. Wrocław-Warszawa-Kraków-Gdańsk.

Lech, J. 1998. Between captivity and freedom: Polish archaeology in the 2oth century. Archaeologia Polona $35-36: 25-222$. 
Mateiciucová, I. 2004. Mesolithic traditions and the origin of the Linear Pottery culture (LBK). In A. Lukes and M. Zvelebil (eds), LBK Dialogues. Studies in the Formation of the Linear Pottery Culture. Oxford, 9I-I08. British Archaeological Reports. International Series I304.

Milojčić, V. 1960. Präkeramisches Neolithikum auf der Balkanhalbinsel. Germania 38: 320-355.

Nowak, M. 2004. Is 'pot prehistory' real prehistory? The case of early LBK. In A. Lukes and M. Zvelebil (eds), LBK Dialogues. Studies in the Formation of the Linear Pottery Culture, 7-15. Oxford. British Archaeological Reports. International Series 1304.

Nowak, M. 2009. Drugi etap neolityzacji ziem polskich. Kraków.

Pavlů, I. 2004. The origins of the early Linear Pottery in Bohemia. In A. Lukes and M. Zvelebil (eds), LBK Dialogues. Studies in the Formation of the Linear Pottery Culture, 83-90. Oxford. British Archaeological Reports. International Series I304.

Pavúk, J. 1980. Ältere Linearkeramik in der Slowakei. Slovenská Archeológia 28: 7-90.

Pavúk, J. 2004. Early Linear Pottery Culture in Slovakia and the Neolithisation of Central Europe. In A. Lukes and M. Zvelebil (eds), LBK Dialogues. Studies in the Formation of the Linear Pottery Culture, 7I-82. Oxford. British Archaeological Reports. International Series I304.

Strien, H.-Ch. and Gronenborn, D. 2005. Klima- und Kulturwandel während des mitteleuropäischen Altneolithikums (58./57. - 51./50. Jahrhundert v. Chr.). In D. Gronnenborn (ed.), Klimaveränderung und Kulturwandel in neolithischen Gesellschaften Mitteleuropas 6700-2200 v. Chr., I3I-I5O. Mainz.

Sztompka, P. 2007. Socjologia zmian spotecznych. Kraków.

Wechler, K.-P. 200I. Studien zum Neolithikum der osteuropäischen Steppe. Mainz. Archäologie in Eurasien I2. Whittle, A. 1996. Europe in the Neolithic: The Creation of the New Worlds. Cambridge.

Whittle, A. 2004. The Archaeology of People. Dimensions of Neolithic Life. London-New York.

Zvelebil, M. 200I. The agricultural transition and the origins of Neolithic society in Europe. Documenta Praehistorica 28: I-27.

Zvelebil, M. 2004. Conclusion: The many origins of the LBK. In A. Lukes and M. Zvelebil (eds), LBK Dialogues. Studies in the Formation of the Linear Pottery Culture, I83-205. Oxford. British Archaeological Reports. International Series 1304. 
